\title{
Role and application of RNA interference in replication of influenza viruses
}

\author{
T. BETÁKOVÁ ${ }^{1,2}$, P. ŠVANČAROVÁ ${ }^{1}$
}

\author{
${ }^{1}$ Institute of Virology, Slovak Academy of Sciences, Dúbravská cesta 9, 84505 Bratislava, Slovak Republic; ${ }^{2}$ Center for Molecular \\ Medicine, Bratislava, Slovak Republic
}

\begin{abstract}
Summary. - RNA interference (RNAi) is a naturally occurring endogenous biological post-transcriptional cellular mechanism that regulates RNA expression. Small interfering RNAs (siRNAs), mediators of RNAi, are short (19-26nt), double-stranded RNA duplexes that inhibit gene expression by inducing sequence-specific degradation of homologous messenger RNA (mRNA). Influenza virus infection is a major public health problem, causing hundreds of thousands of deaths worldwide each year. RNAi have provided a means to performing genome-wide screens to determine and validate host cell genes that may be required for influenza replication and treatment with siRNA specific to regions of the influenza genes which can inhibit influenza virus replication. Moreover, influenza virus is using small RNA in the regulation of virus replication and in modulation of the innate immune signalling system of the host.
\end{abstract}

Keywords: influenza virus; RNA interference; siRNA; miRNA; replication; transcription

\section{Contents:}

1. Introduction

2. RNA interference

3. Regulation function of small viral RNAs (svRNAs)

4. Detection of host cell genes using siRNA technology

5. Cellular miRNA and miRNA inhibitors

6. Effective siRNA targeting virus protein gene

E-mail: virubeta@savba.sk; phone: +421-2-59302440.

Abbreviations: ADAMTS7 = ADAM metallopeptidase with thrombospondin type 1 motif7, CPE = carboxypeptidase E; cRNA = complementary RNA; DPP3 = dipeptidyl-peptidase 3; dsR$\mathrm{NA}=$ double-stranded RNA; HA = hemagglutinin; IL = interleukin; $\mathrm{INF}=$ interferon $; \mathrm{MLC}=$ myosin light chain $; \mathrm{mRNA}=$ messenger RNA; miRNA = micro RNA; MST1 = macrophage stimulating 1; $\mathrm{M} 1=$ matrix protein; $\mathrm{NA}=$ neuraminidase $\mathrm{NCR}=$ noncoding region; $\mathrm{NEP}=$ nuclear export protein; $\mathrm{NP}=$ nucleoprotein; $\mathrm{NS} 1$ = nonstructural protein; $\mathrm{PA}=$ polymerase acidic protein; $\mathrm{PB} 1=$ polymerase basic protein $1 ; \mathrm{PB} 2=$ polymerase basic protein 2 ; pre-miRNA = precursor-micro RNA; pri-miRNA = primary-micro RNA; PRSS12 = neurotrypsin, motopsin; RdRp = RNA-dependent RNA polymerase; RISC $=$ RNA-induced silencing complex; $\mathrm{RNA}=$ ribonucleic acid, RNA $\mathrm{i}=\mathrm{RNA}$ interference; shRNA = short hairpin RNA; siRNA = small interfering RNA; svRNA = small viral RNA; TNF = tumour necrosis factor; $\mathrm{vRNA}=$ viral RNA; $\mathrm{WHO}=$ World Health Organization

\section{Introduction}

The influenza A virus is a highly infectious pathogen of birds and mammals, including humans (Webby and Webster, 2001). Influenza has infected humans in irregular intervals throughout recorded history. The most infamous pandemic was the "Spanish Flu" which affected large parts of the world population and is thought to have killed at least 50 million people between 1918 and 1919. Two other influenza A pandemics occurred in 1957 ("Asian influenza") and 1968 ("Hong Kong influenza") and caused significant global morbidity and mortality. Limited outbreaks of a new influenza subtype A (H5N1) directly transmitted from birds to humans occurred in Hong Kong (Special Administrative Region of China) in 1997 and 2003. From $1^{\text {th }}$ December 2003 to $10^{\text {th }}$ August 2012, 15 countries reported a total of 608 laboratory-confirmed human cases (359 deaths) of H5N1 avian influenza to WHO (www.who.int/influenza/ human_animal_interface). Most recently, the H1N1 virus$\mathrm{A}(\mathrm{H} 1 \mathrm{~N} 1) \mathrm{pdm} 09$ which originated in swine, caused the influenza pandemic in 2009-2010. A new human influenza pandemic could cause $20 \%$ of the global population to become ill (Fouchier et al., 2005).

Influenza A virus is an enveloped virus of the Orthomyxoviridae family. The genome of influenza viruses consists of eight molecules of single-stranded RNA of negative polarity 
that encode the three subunits of the viral polymerase complex, polymerase basic protein $1(\mathrm{~PB} 1)$, polymerase basic protein 2 (PB2), and polymerase acidic protein (PA); the nucleoprotein (NP); the glycoproteins hemagglutinin (HA) and neuraminidase (NA); the matrix protein M1; the ion channel protein M2; the non-structural protein NS1; the nuclear export protein (NEP); and the recently discovered PB1-F2, NP40, PA-X and M42 proteins (Chen et al., 2001; Wise et al., 2009, 2011, 2012; Jagger et al., 2012). The ability of influenza viruses to continuously mutate has made control strategies based on vaccination difficult. Four licensed prescription influenza antiviral agents are currently available: amantadine, rimantadine, Relenza/

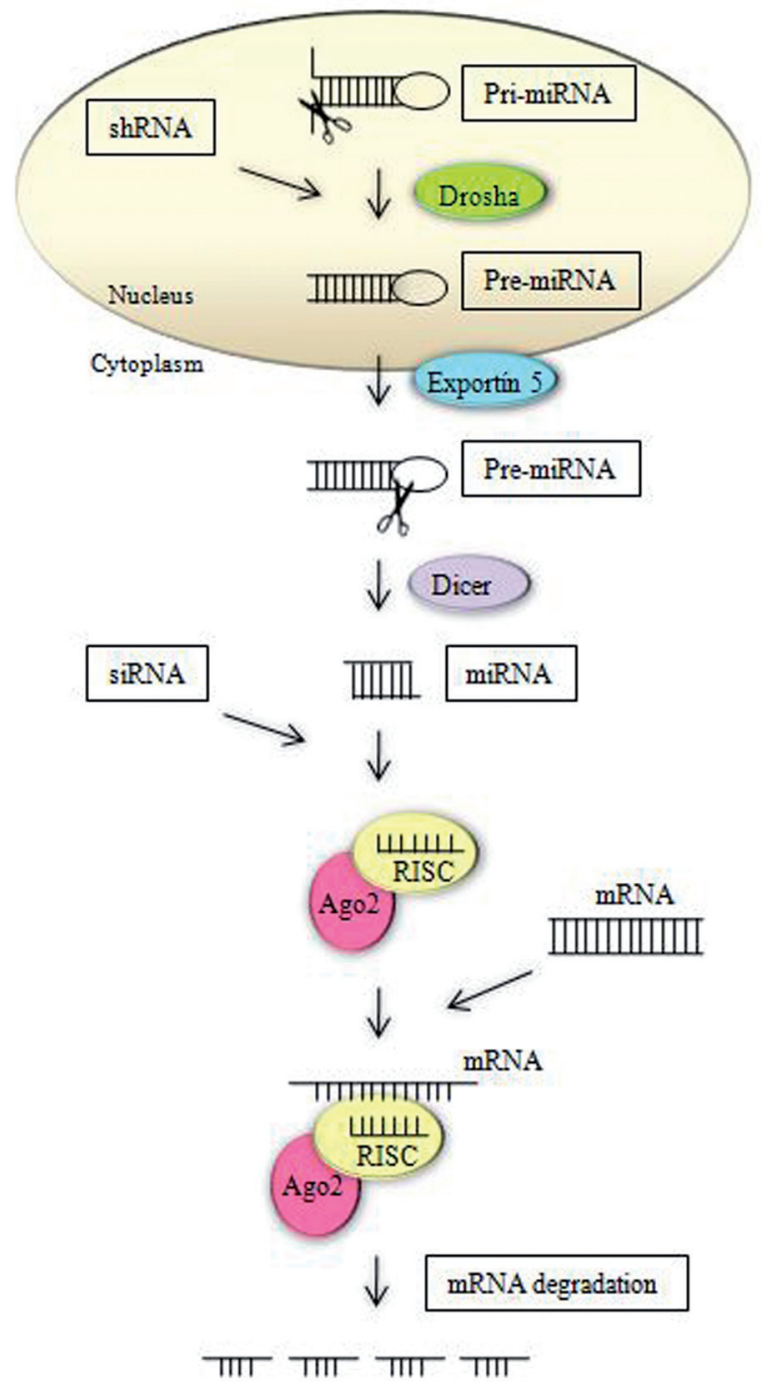

Fig. 1

Pathway of RNAi

Pri-miRNA and shRNAs are processed by Drosha and Dicer to generate mature miRNAs. siRNAs and miRNAs are incorporated into the RISC and guide strand anneals to its complementary target mRNA and facilitates the cleavage by Argonaute 2 to result in gene silencing.
Zanamivir, and Tamiflu/Oseltamivir. Relenza/Zanamivir and Tamiflu/Oseltamivir are related antiviral medications in a class of medications known as neuraminidase inhibitors. These two medications are active against both influenza A and $B$ viruses. Two M2 inhibitors: amantadine and rimantadine are related antiviral drugs in a class of medications known as adamantanes. These medications are active against influenza A viruses but not influenza B viruses. However, widespread adamantane resistance among influenza $\mathrm{A}$ virus strains has made this class of medication less useful clinically. With the potential for a new influenza pandemic and the limited protection provided by current vaccines and antiviral drugs, the development of new and efficient treatment is needed.

\section{RNA interference}

RNAi is a natural, sequence specific post-transcriptional gene silencing pathway present in most eukaryotes (Leung and Whittaker, 2005; Tripp and Tompkins, 2009). Small RNAs contribute to antiviral response in plants, invertebrate and mammals via RNAi involving virus-derived siRNAs (Ding, 2011; Umbach and Cullen, 2009). Components of the RNAi pathway influence multiple roles that can vary in different organisms. Components of the pathway participate i) in the innate immune response by recognizing and degrading long double-stranded RNAs (dsRNAs) associated with viral infection (Bagasra and Prilliman, 2004; Hale et al., 2008); ii) regulate host gene expression related to cell functions by means of a unique class of non-coding RNAs called microRNAs (miRNAs) (Kim and Rossi, 2009).

miRNAs are small RNA molecules with the length of 17 to $24 \mathrm{nt}$. They regulate gene expression either by inhibiting translation of mRNA through seed-region annealing to 3 '-untranslated region of mRNAs or by inducing degradation of mRNA. Primary miRNA (pri-miRNA) transcripts are produced in the nucleus by RNA polymerase II and serve as precursors for generation of miRNA. Short hairpin RNAs (shRNAs), known as precursor-miRNAs (pre-miRNAs), are excised from the primary miRNA by the ribonuclease, Drosha. Pre- miRNAs are exported to the cytoplasm and cleaved with Dicer, resulting in a mature miRNA duplex that is incorporated into the RNA-induced silencing complex (RISC) primed for translation inhibition (Grishok et al., 2001; Hutvagner et al., 2001; Ketting et al., 2001; Miyoshi et al., 2008). miRNAs associated with RISC are able to bind their target and recruit deadenylation factor to remove the poly-A tail of mRNA transcripts (Wu et al., 2006; Giraldes et al., 2006). After deadenylation, decapping enzymes remove the $\mathrm{m} 7 \mathrm{G}$ cap on the $5^{\prime}$-end of mRNA transcripts and promote 5 ' to 3 ' $m$ RNA decay (Fig. 1) (Rehwinkel et al., 2005).

Researchers have created entire libraries of gene-specific targeting reagents which silence individual gene function 
by entering the pathway at one of two distinct positions. Synthetic dsRNA reagents referred to siRNAs have been developed. Inside the cell, siRNA associate with the RISC and guide strand anneals to its complementary target mRNA and facilitates the cleavage by Argonaute 2, a core endonuclease of RISC (Sakurai et al., 2010). shRNAs represent an alternative approach. shRNAs can be generated from plasmid or viral expression constructs (Blakely et al., 2011; Gobeil et al., 2008). Like miRNAs, shRNAs are expressed in the nucleus and associated with RISC only after being processed by two separate endonucleses, Drosha and Dicer (Fig.1) (Kim and Rossi, 2009).

Influenza virus uses small RNA in regulation of virus replication and in modulation of the innate immune signalling system of the host (Perez et al., 2010; Buggele et al., 2012). shRNAs and siRNAs provide the valuable tools for identification of host proteins involved in viral replication and for an alternative disease intervention approach to controlling influenza virus replication (Hirsch, 2010; Meliopoulos et al., 2012). siRNA libraries have been constructed with a variety of design and it is important to consider which of these siRNAs are best suited for host-pathogen screening.

\section{Regulation function of small viral RNAs (svRNAs)}

Regulatory function of small RNAs continues to reshape paradigm in both molecular biology and virology. svRNAs of influenza A virus elucidate a unique mechanism by which a virus can control the switch between transcription and replication (Perez et al., 2010).

The influenza A virus genome consists of eight negativesense, single-stranded RNA segments, which serve as templates for the transcription of viral mRNAs and full length complementary RNAs (cRNAs). cRNA are replicated to produce viral RNAs (vRNAs). The RNA promoter for the influenza virus RNA-dependent RNA polymerase (RdRp) consists of 12 conserved nucleotides at the 5 ' -and 3 '-ends of the vRNA, respectively (Robertson 1979, Hsu et al., 1987). RdRp binds the double stranded panhandle/corkscrew structure, which is formed by these non-coding regions (NCRs) along with additional segment-specific bases (Desselberger et al., 1980; Neuman and Hobon, 1995; Flick et al., 1996; Brownlee and Sharps 2002; Crow et al., 2004). The RdRp associates with the secondary structure of the viral NCRs and initiates transcription beginning at the first 3 'cytosine (Plotch et al., 1981). The PB2 protein gets host mRNAs under control, and the PA protein cleaves cca 11-13 bases downstream of the 5 ' cap. The PB1 protein then uses this fragment to synthesize viral mRNA (Plotch et al., 1981; Guiligay et al., 2008; He et al., 2008; Dias et al., 2009). Initiation and elongation of the transcript depends on a stable association with the 5 '-end of vRNA (Honda et al., 1987). The RdRp reaches the $5^{\prime}$-end of the template vRNA, which must then interact with the 3 '-end of the same template. This is necessary for the occurrence of polyadenylation (Poon et al., 1998; Leahy et al., 2001). Cis-acting RdRp is required for the polyadenylation of influenza virus. Transcriptase activity composed of $\mathrm{PA}$ and PB2 cap-snatching and PB1 polymerase function is dependent on utilization of the secondary structure of the vRNA for proper synthesis of viral mRNA. Accumulation of mRNAs leads to protein production which must be followed by a switch to viral replicase activity for generation of new vRNAs and assembly of virions. mRNA transcripts are incomplete copies of vRNA and therefore cannot be used as substrates for genomic synthesis. vRNA synthesis takes place through a cRNA intermediate, also made by the RdRp from vRNA but representing a full-length complement of the vRNA. Key components which influence the viral switch to replication include cRNA stability, the intracellular level of nucleotides, and the soluble fraction of NP and/or RdRp (Shapiro and Krug, 1988; Vreede et al., 2004; Vreede et al., 2008; Jorba et al., 2009).

Perez et al. (2010) established a new model in which svRNA regulates the level of vRNA synthesis during de novo virus infection. svRNAs are 22-27 nt in length and correspond to the $5^{\prime}$-end of each of the vRNA segments. It is thought that svRNAs are synthesizes by $\mathrm{RdRp}$ from cRNA. NP function may be required to temporally block the secondary structure of the panhandle and allow complete cRNA synthesis (Beaton and Krug, 1986). NEP protein also participates in the generation of svRNA (Robb et al., 2009). It is likely that svRNA aids in the formation of an alternative RdRp replicase complex, an attribute bestowed upon NEP protein. NEP protein is involved not only in RNA trafficking but also in the switch between transcription and replication. The RdRp replicase may consist of an NEP containing RdRp bound to svRNA, and the transcriptase probably lacks svRNAs. svRNA regulates vRNA replication in a segment -specific manner and therefore the existence of eight different $\mathrm{RdRp}$ replicases is required. The physical association of the RdRp with svRNA within the replicase could serve as a segment-specific guide capable of reconstituting the promoter in trans, thereby permitting access to the genomic ends (Perez et al., 2010). On the other hand, lack of svRNA in transcriptase would permit the stuttering needed to generate the poly A tail during viral mRNA synthesis, because the RdRp remains bound in cis to the 5 '-end of the vRNA template (Fig. 2).

\section{Detection of host cell genes using siRNA technology}

RNAi have provided a means to performing genomewide screens to determine and validate host cell genes which may be required for influenza replication. These 
genes have been also identified by random homozygous gene perturbation and by a proteomic screen (Sui et al., 2009; Bradel-Tretheway et al., 2011). It has to be taken into consideration that impairing of non-targeted mRNA may result in the misinterpretation of the phenotype produced by an individual siRNA. For this reason, large siRNA libraries are designed to contain component siRNA with minimal sequence complementarities to other mRNAs. Each specific mRNA is targeted by multiple siRNAs in order to increase the change that at least one siRNA will produce adequate target degradation. Another factor affecting the ability of a particular siRNA to reduce the expression of target proteins is the stability of these proteins. Proteins with a long half-life may be less susceptible to knock-down because they remain in the cell at close to a normal level even if the encoding mRNA has been diminished. In this case, multiple siRNA transfection over several days may be used in order to suppress the level of the mRNA for a longer period of time. Another factor that must be considered is efficiency of transfection (Hirsch, 2010).
Based on genome-wide RNAi screening, König et al. (2010) identified 295 cellular cofactors required for early-stage influenza virus replication. Most proteins are involved in kinase-regulated signalling, ubiquitination and phosphatase activity. 181 factors assemble into a highly significant host-pathogen interaction network. 219 of the 295 factors were confirmed to be required for efficient wild-type influenza virus growth, and further analysis of a subset of genes showed 23 factors necessary for viral entry, including members of the vacuolar ATPase and COPI-protein families, fibroblast growth factor receptor proteins, and glycogen synthase kinase 3-beta. 10 proteins were confirmed to be involved in postentry steps of influenza virus replication. These include nuclear import components, proteases, and the calcium/ calmodulin-dependent protein kinase IIbeta (König et al., 2010).

Some human proteases have a direct role in the replication of influenza virus. shRNA inhibition of trypsin inhibited replication and apoptosis (Pan et al., 2011).

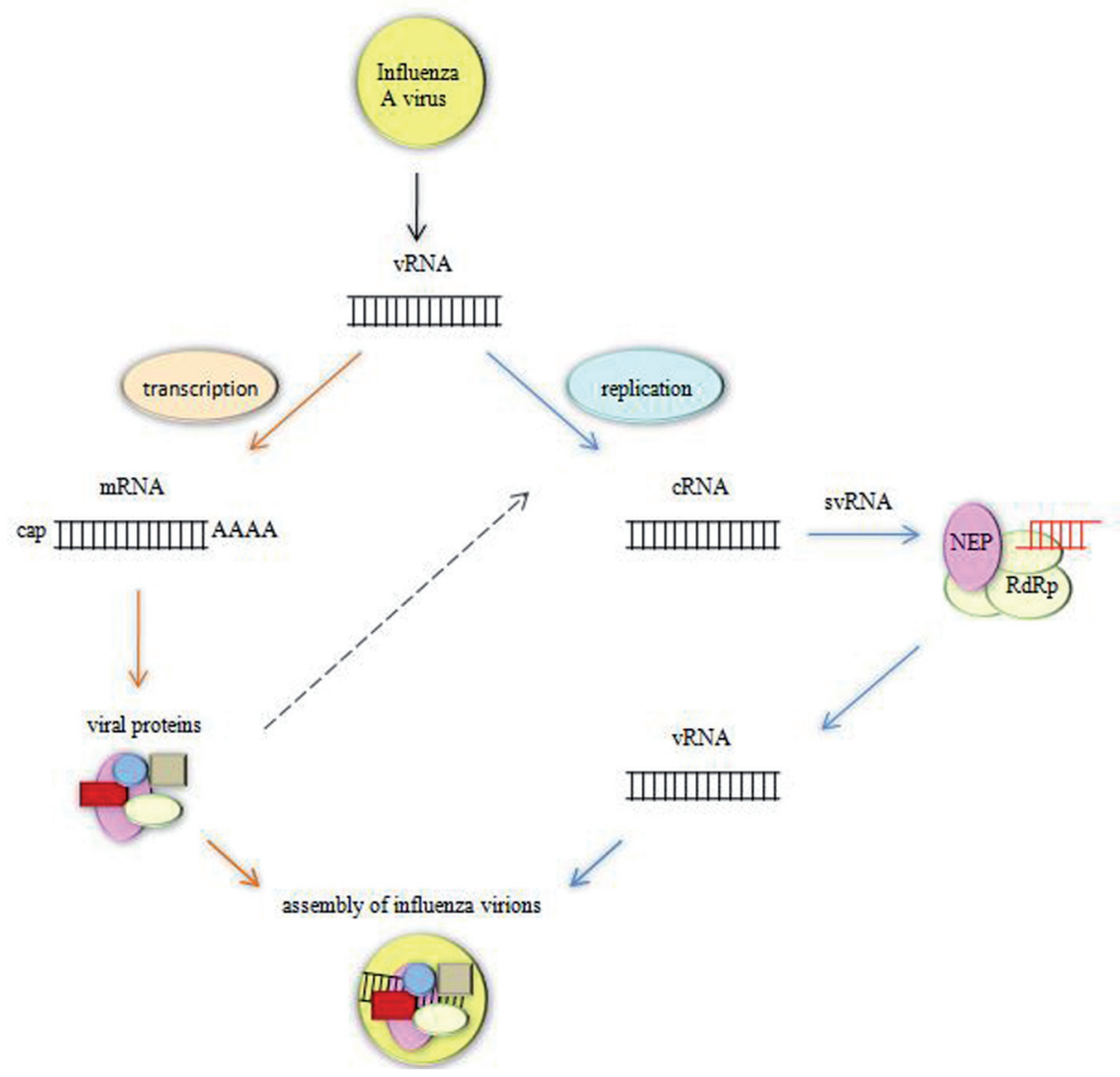

Fig. 2

Schematic diagram of the influenza virus life cycle

Single-stranded RNA segments serves as templates for the transcription of viral mRNAs and full length cRNAs and svRNAs. cRNA are replicated to produce vRNAs. svRNAs play a key role in regulation of vRNA replication as it is described in the text. The picture is adopted from Scull and Rice (2010). 
Five genes encoded ADAM metallopeptidase with thrombospondin type 1, motif 7 (ADAMTS7), carboxypeptidase E (CPE), dipeptidyl-peptidase 3 (DPP3), macrophage stimulating 1 (MST1), and neurotrypsin, motopsin (PRSS12) were identified by RNAi (Meliopoulos et al., 2012). These genes are involved in three identified host cell pathways, specifically CRE/CREB signalling, NF- $\kappa \mathrm{B}$ activation, and apoptosis. With respect to influenza virus, CRE/CREB signalling has been shown to activate protein kinase $A$ and thus have a role in protein synthesis (Stakkestad et al., 2011). ADAMTS7 is unregulated by TNF- $\alpha$ and IL- $1 \beta$ secretion, both of which are activated upon influenza infection (Luan et al., 2008; Wang et al., 2010).

Abrogation of RAB11A expression through siRNA treatment caused aberrant vRNP intracellular accumulation, retention in the perinuclear region, and lack of accumulation at the plasma membrane. RAB11 GTPase is involved in the transport of ribonucleoprotein cargo (Amorim et al., 2011; Eisfeld et al., 2011).

Influenza infection also activates the signalling pathways that converge to induce myosin light chain (MLC) phosphorylation and actin cytoskeleton remodelling (Haidari et al., 2011). Inhibition of MLC phosphorylation led to the nuclear retention of viral RNP complexes in late stages of viral replication cycle, thus reducing proliferation of the influenza virus.

Human Staufen1 (hStau1) protein is involved in the transport and regulated translation of cellular mRNAs (Villace et al., 2004). This protein was also identified as an NS1-interacting factor. Expression of hStaul protein was downregulated by gene silencing using shRNA or siRNAs targeting four independent sites in human HEK293 and A549 cells. Silencing hStaul protein resulted in significant reduction of the yield of influenza virus. These results indicate a role for $\mathrm{hStau} 1$ protein in late event of influenza virus infection, possibly during virus morphogenesis (de Lucas et al., 2010).

Transfection of small dsRNA can also perturb cellular immunity. siRNA longer than 23-25 bp strongly up-regulated interferon- stimulated genes in HeLa cells (Kim et al., 2004). siRNAs can also activate a type I interferon response, particularly through TLR7 and TLR8 (Hornung et al., 2005; Sioud, 2005). On the other hand, 19 bp long siRNAs effectively silence genes but are weaker activators of TLR signalling pathway (Reynolds et al., 2006). The immunostimulation can also be suppressed by suitable chemical modifications without losing siRNA potency by introducing seemingly minor structural changes. Oligoribonucleotides with 2'-O-methyladenosine residues actively inhibited IFN-alpha secretion induced by other immunostimulatory RNAs (Eberle et al., 2008).

\section{Cellular miRNA and miRNA inhibitors}

Expression of host genes required for influenza virus replication can be regulated by multiple miRNAs. Targeting
miRNAs to regulate host gene expression may be a strategy to regulate influenza virus replication. While miRNAs modulate host gene expression, they likely modulate influenza virus replication indirectly and perhaps at different points in the replication pathway. Some miRNA inhibitors had a different effect on host genes required for influenza virus replication. For example, inhibition of miR-106B had little effect on CPE gene expression but dramatically increased DPP3, ADAMTS7, MST1, and PRSS12 gene expression (Meliopoulos et al., 2012).

Examination of miRNA abundance in human lung cell lines revealed endogenous miRNA, including miR-7, miR-132, miR-146a, miR-187, miR-200c, and miR-1275. Gene expression profiling identified 26 cellular mRNAs targeted by these miRNAs, including IRAK1, MAPK3, and other components of the innate immune signalling system. (Buggele et al., 2012). MAPK3 and IRAK1 are targeted for mRNA degradation and protein inhibition by the combinatorial effect of miR-132 and miR-1275, and miR-146a and miR-1275, respectively. Some of these miRNAs have the ability to regulate the innate immune signalling pathways. miR-132 is regulated transcriptionally by a MAPK3 (ERK1) pathway and it has been suggested that MAPK3 can use miR-132 to regulate its activity in a negative feedback loop (Remenyi et al., 2010; Kawashima et al., 2010).

Cellular miR-323, miR-491, and miR-654 inhibit replication of H1N1 influenza virus through binding the PB1 gene (Song et al., 2010).

\section{Effective siRNA targeting virus protein gene}

Anti-influenza potency of a synthetic siRNA is first tested in cultured cells by using a series of siRNA concentration. The siRNA that show potency against influenza virus in cell cultures are then tested on the animal model, usually on the mouse.

Ge et al. (2003) showed that pre-treatment of MDCK cells with siRNA specific for NP (1496-1514) or PA (2087-2106) could inhibit influenza virus replication after infection in vitro. Tomkins et al. continued experimental work with these siRNAs in vivo. A mixture of siRNAs specific for highly conserved regions of the NP (siNP-1496) and PA (siPA-2087) can protect mice from lethal challenge of influenza virus. Moreover, these siRNAs were broadly effective and protected animals against lethal challenge with highly pathogenic avian influenza A viruses of the $\mathrm{H} 5$ and $\mathrm{H} 7$ subtypes (Tomkins et al., 2004; Ge et al., 2004; Suzuki et al., 2009).

Rationally designed siRNA targeting M2 gene (psM-950) exhibited similar or even slightly higher inhibitory effect against influenza virus replication compared to that of siNP1496 (Sui et al., 2009).

The NP-specific siRNA (psNP-749 and psNP-1383) can efficiently down-regulate the expression of NP and 
the M2-specific siRNAs (psM-48, psM-754, psM-949) can down-regulate the expression of M2 protein (Zhou et al., 2007). Lung virus titres were reduced (16-50\%) in the mice pre-treated with the NP specific siRNA (psNP-1383) together with the M2-specific siRNA (psM-48).

The oligonucleotide, PB1-shRNA, containing a 21-bp siRNA corresponding to nucleotides 1632-1652 of linear vRNA, inhibits influenza A virus replication both in vitro and in vivo. The virus titer in cell culture supernatant (MDCK cells) was inhibited more than 50-fold, in embryonated eggs by a 100 -fold. The survival rate oscillated between $50 \%$ and $100 \%$ in experimental mice (Li et al., 2011).

Viral replication in the siRNA targeting PA (ps-PA496) treated cells was 78-fold lower than that of the control cells. This siRNA significantly decreased the viral titre in the lungs of infected mice (Zhang et al., 2009).

$21 \mathrm{nt}$ duplexes of siRNA of the influenza virus $M$ gene can cause specific inhibition of M1 protein expression in transfected 293T cells. siRNAs from different regions of $\mathrm{M}$ gene (psM-89, psM-331, and psM-620) had a varying effect in suppressing M1 protein synthesis. siRNA targeting the 331-351 region of the $M$ gene was most effective in inhibiting translation of the M1 protein (Hui et al., 2004).

Replication of the influenza virus can be also inhibited by suppressing NS1 protein. Antisense oligonucleotides with 2 '-O-methyl modification on one end and 3 '-butanoo tag modification on the other end decreased 5-fold hem agglutination titer on chicken fibroblast cells. Oligonucleotides NS2, NS27, and NS526 protected the infected chicken from H5N1 virus up to $50 \%$ and a mixture of the three oligonucleotides could protect $87.5 \%$ of infected chickens (Wu et al., 2008).

Acknowledgement. This publication is the result of the project implementation: TRANSMED 2, ITMS: 26240120030, supported by the Research \& Development Operational Program funded by the ERDF and by the VEGA Scientific Grant Agency (grant No. 2/0005/12).

Conflict of interest. The authors declare that there is no conflict of interest with the ideas put forward in the final version of manuscript.

\section{References}

Amorim MJ, Bruce EA, Read EK, Foeglein A, Mahen R, Stuart AD, Digard P, J. Virol. 85, 4143-4156, 2011. http://dx.doi. org/10.1128/JVI.02606-10

Bagasra O, Prilliman KR, J. Mol. Histol. 35, 545-553, 2004. http:// dx.doi.org/10.1007/s10735-004-2192-8

Beaton AR, Krug RM, Proc. Natl. Acad. Sci. USA 83, 6282-6286, 1986. http://dx.doi.org/10.1073/pnas.83.17.6282

Blakely K, Ketela T, Moffat J, Methods Mol. Biol. 781, 161-182, 2011. http://dx.doi.org/10.1007/978-1-61779-276-2 9
Bradel-Tretheway BG, Mattiacio JL, Krasnoselsky A, Stevenson C, Purdy D, Dewhurst S, Katze MG, J. Virol. 85, 8569-8581, 2011. http://dx.doi.org/10.1128/JVI.00496-11

Brownlee GG, Sharps JL, J. Virol. 76, 7103-7113, 2002. http://dx.doi. org/10.1128/JVI.76.14.7103-7113.2002

Buggele WA, Johnson KE, Horvath CM, J. Biol. Chem. 287, 31027-31040, 2012. http://dx.doi.org/10.1074/jbc. M112.387670

Crow M, Deng T, Addley M, Brownlee GG, J. Virol. 78, 62636270, 2004. http://dx.doi.org/10.1128/JVI.78.12.6263$\underline{6270.2004}$

Chen W, Calvo PA, Malide D, Gibbs J, Schubert U, Bacik I, Basta S, O'Neill R, Schickli J, Palese P, Henklein P, Bennink JR, Yewdell JW, Nat. Med. 7, 1306-1312, 2001. http://dx.doi. org/10.1038/nm1201-1306

de Lucas S, Peredo J, Marion RM, Sanchez C, Ortín J, J. Virol. 84, 7603-7612, 2010. http://dx.doi.org/10.1128/JVI.00504$\underline{10}$

Dias A, Bouvier D, Crepin T, McCarthy AA, Hart DJ, Baudin F, Cusack S, Ruigrok RW, Nature 458, 914-918, 2009. http:// dx.doi.org/10.1038/nature07745

Ding SW, Lu R, Curr. Opin. Virol. 1, 533-544, 2011. http://dx.doi. org/10.1016/j.coviro.2011.10.028

Eberle F, Giessler K, Deck C, Heeg K, Peter M, Richert C, Dalpke AH, J. Immunol. 180, 3229-3237, 2008.

Eisfeld AJ, Kawakami E, Watanabe T, Neumann G, Kawaoka Y, J. Virol. 85, 6117-6126, 2011. http://dx.doi.org/10.1128/ JVI.00378-11

Flick R, Neumann G, Hoffmann E, Neumeier E, Hobom G, RNA 2, 1046-1057, 1996.

Fouchier R, Kuiken T, Rimmelzwaan G, Osterhaus A, Nature 435, 419-420, 2005. http://dx.doi.org/10.1038/435419a

Ge Q, McManus MT, Nguyen T, Shen CH, Sharp PA, Eisen HN, Chen J, Proc. Natl. Acad. Sci. USA 100, 2718-2723, 2003. http://dx.doi.org/10.1073/pnas.0437841100

Ge Q, Filip L, Bai A, Nguyen T, Eisen HN, Chen J, Proc. Natl. Acad. Sci. USA 101, 8676-8681, 2004. http://dx.doi.org/10.1073/ pnas. 0402486101

Giraldez AJ, Mishima Y, Rihel J, Grocock RJ, Van Dongen S, Inoue K, Enright AJ, Schier AF, Science 312, 75-79, 2006. http:// dx.doi.org/10.1126/science.1122689

Gobeil S, Zhu X, Doillon CJ, Green MR, Genes Dev. 22, 2932-2940, 2008. http://dx.doi.org/10.1101/gad.1714608

Grishok A, Pasquinelli AE, Conte D, Li N, Parrish S, Ha I, Baillie DL, Fire A, Ruvkun G, Mello CC, Cell 106, 23-34, 2001. http://dx.doi.org/10.1016/S0092-8674(01)00431-7

Guilligay D, Tarendeau F, Resa-Infante P, Coloma R, Crepin T, Sehr P, Lewis J, Ruigrok RW, Ortín J, Hart DJ, Cusack S, Nat. Struct. Mol. Biol. 15, 500-506, 2008. http://dx.doi. org/10.1038/nsmb.1421

Haidari M, Zhang W, Ganjehei L, Ali M, Chen Z, PLoS One 6:e21444, 2011. http://dx.doi.org/10.1371/journal.pone.0021444

Hale BG, Randall RE, Ortin J, Jackson D, J. Gen. Virol. 89, 2359-2376, 2008. http://dx.doi.org/10.1099/vir.0.2008/004606-0

He X, Zhou J, Bartlam M, Zhang R, Ma J, Lou Z, Li X, Li J, Joachimiak A, Zeng Z, Ge R, Rao Z, Liu Y, Nature 454, 1123-1126, 2008. http://dx.doi.org/10.1038/nature07120 
Hirsch AJ, Future Microbiol. 5, 303-311, 2010. http://dx.doi. org/10.2217/fmb.09.121

Honda A, Uéda K, Nagata K, Ishihama A, J. Biochem. 102, 12411249, 1987.

Hornung V, Guenthner-Biller M, Bourquin C, Ablasser A, Schlee M, Uematsu S, Noronha A, Manoharan M, Akira S, de Fougerolles A, Endres S, Hartmann G, Nat. Med. 11, 263270, 2005. http://dx.doi.org/10.1038/nm1191

Hsu MT, Parvin JD, Gupta S, Krystal M, Palese P, Proc. Natl. Acad. Sci. USA 84, 8140-8144, 1987. http://dx.doi.org/10.1073/ pnas.84.22.8140

Hui EK, Yap EM, An DS, Chen IS, Nayak DP, J. Gen. Virol. 85, 1877 1884, 2004. http://dx.doi.org/10.1099/vir.0.79906-0

Hutvagner G, McLachlan J, Pasquinelli AE, Balint E, Tuschl T, Zamore PD, RNA. Science 293, 834-838, 2001.

Jagger BW, Wise HM, Kash JC, Walters KA, Wills NM, Xiao YL, Dunfee RL, Schwartzman LM, Ozinsky A, Bell GL, Dalton RM, Lo A, Efstathiou S, Atkins JF, Firth AE, Taubenberger JK, Digard P, Science 337, 199-204, 2012. doi: 10.1126/ science.1222213.

Jorba N, Coloma R, Ortín J, PLoS Pathog. 5:e1000462, 2009. http:// dx.doi.org/10.1371/journal.ppat.1000462

Kawashima H, Numakawa T, Kumamaru E, Adachi N, Mizuno $\mathrm{H}$, Ninomiya M, Kunugi H, Hashido K, Neuroscience 165, 1301-1311, 2010. http://dx.doi.org/10.1016/j.neuroscience.2009.11.057

Ketting RF, Fischer SE, Bernstein E, Sijen T, Hannon GJ, Plasterk RH, Genes Dev. 15, 2654-2659, 2001. http://dx.doi. org/10.1101/gad.927801

Kim DH, Longo M, Han Y, Lundberg P, Cantin E, Rossi JJ, Nat. Biotechnol. 2004 22, 321-325, 2004. http://dx.doi. org/10.1038/nbt940

Kim DH, Rossi JJ, Methods Mol. Biol. 555, 119-125, 2009. http:// dx.doi.org/10.1007/978-1-60327-295-7_9

König R, Stertz S, Zhou Y, Inoue A, Hoffmann HH, Bhattacharyya S, Alamares JG, Tscherne DM, Ortigoza MB, Liang Y, Gao Q, Andrews SE, Bandyopadhyay S, De Jesus P, Tu BP, Pache L, Shih C, Orth A, Bonamy G, Miraglia L, Ideker T, García-Sastre A, Young JA, Palese P, Shaw ML, Chanda SK, Nature 463, 813-817, 2010. http://dx.doi.org/10.1038/ nature08699

Leahy MB, Pritlove DC, Poon LL, Brownlee GG, J. Virol. 75, 134-142, 2001. http://dx.doi.org/10.1128/JVI.75.1.134142.2001

Leung RK, Whittaker PA, Pharmacol. Ther. 107, 222-239, 2005. http://dx.doi.org/10.1016/j.pharmthera.2005.03.004

Li W, Yang X, Jiang Y, Wang B, Yang Y, Jiang Z, Li M, Arch. Virol. 156, 1979-1987, 2011. http://dx.doi.org/10.1007/s00705011-1087-8

Luan Y, Kong L, Howell DR, Ilalov K, Fajardo M, Bai XH, Di Cesare PE, Goldring MB, Abramson SB, Liu CJ, Osteoarthritis Cartilage 16, 1413-1420, 2008. http://dx.doi. org/10.1016/j.joca.2008.03.017

Meliopoulos VA, Andersen LE, Birrer KF, Simpson KJ, Lowenthal JW, Bean AG, Stambas J, Stewart CR, Tompkins SM, van Beusechem VW, Fraser I, Mhlanga M, Barichievy S, Smith Q, Leake D, Karpilow J, Buck A, Jona G, Tripp RA,
FASEB J. 26, 1372-1386, 2012. http://dx.doi.org/10.1096/ f. $11-193466$

Meliopoulos VA, Andersen LE, Brooks P, Yan X, Bakre A, Coleman JK, Tompkins SM, Tripp RA, PLoS One 7:e37169, 2012. http://dx.doi.org/10.1371/journal.pone.0037169

Miyoshi K, Uejima H, Nagami-Okada T, Siomi H, Siomi MC, Methods Mol. Biol. 442, 29-43, 2008. http://dx.doi. org/10.1007/978-1-59745-191-8 3

Neumann G, Hobom G, J. Gen. Virol. 76, 1709-1717, 1995. http:// dx.doi.org/10.1099/0022-1317-76-7-1709

Pan HY, Yamada H, Chida J, Wang S, Yano M, Yao M, Zhu J, Kido H, Cardiovasc. Res. 89, 595-603, 2011. http://dx.doi. org/10.1093/cvr/cvq358

Perez JT, Varble A, Sachidanandam R, Zlatev I, Manoharan M, García-Sastre A, tenOever BR, Proc. Natl. Acad. Sci. USA 107, 11525-11530, 2010. http://dx.doi.org/10.1073/ pnas.1001984107

Plotch SJ, Bouloy M, Ulmanen I, Krug RM, Cell 23, 847-858, 1981. http://dx.doi.org/10.1016/0092-8674(81)90449-9

Poon LL, Pritlove DC, Sharps J, Brownlee GG, J. Virol. 72, 82148219, 1998.

Rehwinkel J, Behm-Ansmant I, Gatfield D, Izaurralde E, RNA 11, 1640-1647, 2005. http://dx.doi.org/10.1261/ rna.2191905

Reynolds A, Anderson EM, Vermeulen A, Fedorov Y, Robinson K, Leake D, Karpilow J, Marshall WS, Khvorova A, RNA 12, 988-993, 2006. http://dx.doi.org/10.1261/rna.2340906

Remenyi J, Hunter CJ, Cole C, Ando H, Impey S, Monk CE, Martin KJ, Barton GJ, Hutvagner G, Arthur JS, Biochem. J. 13, 281-291, 2010. http://dx.doi.org/10.1042/BJ20100024

Robertson JS, Nucleic Acids Res. 6, 3745-3757, 1979. http://dx.doi. org/10.1093/nar/6.12.3745

Robb NC, Smith M, Vreede FT, Fodor E, J. Gen. Virol. 90, 13981407, 2009. http://dx.doi.org/10.1099/vir.0.009639-0

Sakurai K, Chomchan P, Rossi JJ, Curr. Protoc. Cell Biol. 27, 1-28, 2010.

Shapiro GI, Krug RM, J. Virol. 62, 2285-2290, 1988.

Sui B, Bamba D, Weng K, Ung H, Chang S, Van Dyke J, Goldblatt M, Duan R, Kinch MS, Li WB, Virology 387, 473-481, 2009. http://dx.doi.org/10.1016/j.virol.2009.02.046

Sioud M, J. Mol. Biol. 348, 1079-1090, 2005. http://dx.doi. org/10.1016/i.jmb.2005.03.013

Song L, Liu H, Gao S, Jiang W, Huang W, J. Virol. 84, 8849-8860, 2010. http://dx.doi.org/10.1128/JVI.00456-10

Stakkestad Ø, Larsen AC, Kvissel AK, Eikvar S, Ørstavik S, Skålhegg BS, BMC Biochem.12, 7, 2011. http://dx.doi. org/10.1186/1471-2091-12-7

Sui HY, Zhao GY, Huang JD, Jin DY, Yuen KY, Zheng BJ, 4:e5671, 2009.

Suzuki H, Saitoh H, Suzuki T, Takaku H, Nucleic Acids Symp. Ser. 53, 287-288, 2009. http://dx.doi.org/10.1093/nass/ nrp144

Tompkins SM, Lo CY, Tumpey TM, Epstein SL, Proc. Natl. Acad. Sci. USA 101, 8682-8686, 2004. http://dx.doi.org/10.1073/ pnas. 0402630101

Tripp RA, Tompkins SM, Methods Mol. Biol. 555, 43-61, 2009. http://dx.doi.org/10.1007/978-1-60327-295-7 4 
Umbach JL, Cullen BR, Genes Dev. 23, 1151-1164, 2009. http:// dx.doi.org/10.1101/gad.1793309

Villacé P, Marión RM, Ortín J, Nucleic Acids Res. 32, 2411-2420, 2004. http://dx.doi.org/10.1093/nar/gkh552

Vreede FT, Jung TE, Brownlee GG, J. Virol. 78, 9568-9572, 2004. http://dx.doi.org/10.1128/JVI.78.17.9568-9572.2004

Vreede FT, Gifford H, Brownlee GG, J. Virol. 82, 6902-6910, 2008. http://dx.doi.org/10.1128/JVI.00627-08

Wang S, Le TQ, Kurihara N, Chida J, Cisse Y, Yano M, Kido H, J. Infect. Dis. 202, 991-1001, 2010. http://dx.doi. org/10.1086/656044

Webby RJ, Webster RG, Trans. R. Soc. Lond. B. Biol. Sci 356, 1817-1828, 2001. http://dx.doi.org/10.1098/ rstb.2001.0997

Wise HM, Foeglein A, Sun J, Dalton RM, Patel S, Howard W, Anderson EC, Barclay WS, Digard P, J. Virol. 83, 8021-31, 2009. doi: 10.1128/JVI.00826-09.
Wise HM, Barbezange C, Jagger BW, Dalton RM, Gog JR, Curran MD, Taubenberger JK, Anderson EC, Digard P, Nucleic Acids. Res. 39, 7775-7790, 2011. http://dx.doi. org/10.1093/nar/gkr487

Wise HM, Hutchinson EC, Jagger BW, Stuart AD, Kang ZH, Robb N, Schwartzman LM, Kash JC, Fodor E, Firth AE, Gog JR, Taubenberger JK, Digard P, PLoS Pathog. 8, e1002998, 2012. doi: 10.1371/journal.ppat.1002998.

Wu L, Fan J, Belasco JG, Proc. Natl. Acad. Sci. USA 103, 4034-4039, 2006. http://dx.doi.org/10.1073/pnas.0510928103

Wu Y, Zhang G, Li Y, Jin Y, Dale R, Sun LQ, Wang M, Biochem. Biophys. Res. Commun. 365, 369-374, 2008. http://dx.doi. org/10.1016/j.bbrc.2007.10.196

Zhang W, Wang CY, Yang ST, Qin C, Hu JL, Xia XZ, Biochem. Biophys. Res. Commun. 390, 421-426, 2009. http://dx.doi. org/10.1016/j.bbrc.2009.09.039

www.who.int/influenza/human_animal_interface 